\title{
Long-distance dispersal, low connectivity and molecular evidence of a new cryptic species in the obligate rafter Caprella andreae Mayer, 1890 (Crustacea: Amphipoda: Caprellidae)
}

\author{
M. Pilar Cabezas · Carlos Navarro-Barranco • \\ Macarena Ros · José Manuel Guerra-García
}

Received: 22 May 2012/Revised: 15 October 2012/Accepted: 18 October 2012/Published online: 1 November 2012

(C) Springer-Verlag Berlin Heidelberg and AWI 2012

\begin{abstract}
The amphipod Caprella andreae Mayer, 1890 was recorded for the first time in Southern Iberian Peninsula $\left(36^{\circ} 44^{\prime} 15^{\prime \prime} \mathrm{N}, 3^{\circ} 59^{\prime} 38^{\prime \prime} \mathrm{W}\right)$. This species is the only obligate rafter of the suborder Caprellidea and has been reported to attach not only to floating objects such as ropes or driftwoods but also to turtle carapaces. Mitochondrial and nuclear markers were used to examine dispersal capabilities and population genetic structure of $C$. andreae across seven localities in the Mediterranean and Atlantic Ocean collected from floating substrata with different dispersal patterns. The strong population differentiation with no haplotypes shared between populations suggests that C. andreae is quite faithful to the substratum on which it settles. In addition, the proportionally higher genetic diversity displayed in populations living on turtles as well as the presence of highly differentiated haplotypes in the same turtle population may be indicative that these populations survive longer, which could lead $C$. andreae to prefer turtles instead of floating objects to settle and disperse. Therefore, rafting on floating objects may be sporadic, and ocean currents would not be the most important factor shaping patterns of connectivity and population structure in this species. Furthermore, molecular phylogenetic analyses revealed the existence of a cryptic species
\end{abstract}

Communicated by L. Gutow.

M. P. Cabezas $(\bowtie) \cdot$ C. Navarro-Barranco · M. Ros ·

J. M. Guerra-García

Laboratorio de Biología Marina, Departamento de Zoología,

Facultad de Biología, Universidad de Sevilla,

Avda. Reina Mercedes 6, 41012 Sevilla, Spain

e-mail: pilarcabezas@us.es whose estimates of genetic divergence are higher than those estimated between $C$. andreae and other congeneric species (e.g. Caprella dilatata and Caprella penantis). Discovery of cryptic species among widely distributed small marine invertebrates is quite common and, in this case, prompts for a more detailed phylogenetic analysis and taxonomic revision of genus Caprella. On the other hand, this study also means the first record of the gammarids Jassa cadetta and Elasmopus brasiliensis and the caprellid Caprella hirsuta on drifting objects.

Keywords Caprella andreae - Rafting - mtDNA . Drifting rope $\cdot$ Caretta caretta $\cdot$ Cryptic species

\section{Introduction}

A good insight into the dispersal capability of marine organisms is of major importance for a more informed understanding about the ecology and evolution of these species. Dispersal capability has a significant effect on the geographic distribution and abundance of individuals, populations and communities, and determines the degree of genetic connectivity between populations of a species (Palumbi 2003). Among benthic marine invertebrates, dispersal is typically accomplished by planktonic larvae, which are capable of dispersing passively in ocean currents, thus promoting genetic connectivity between geographically distant locations (Scheltema 1988; Ribeiro et al. 2010). On the other hand, many marine species have direct development, lacking planktonic larvae, which imposes restrictions on their dispersal potential (Thiel 2003; Teske et al. 2007). However, there is increasing evidence that the duration of pelagic stages is not directly correlated with dispersal potential (Johannesson 1988; 
Strathmann et al. 2002). This is supported by the fact that many brooding species have wider geographic distributions showing even more genetic connectivity on large scales than congeners with a planktonic larval stage (Highsmith 1985; Ó Foighil et al. 2001; Nunes et al. 2011; Hoeksema et al. 2012; Xavier et al. 2012). Passive dispersal through rafting and floating can greatly enhance natural dispersal in the marine environment and is supposed to be the main process leading to long-distance dispersal of these brooding marine invertebrates (Johannesson 1988; Locke and Corey 1989; Thiel and Gutow 2005b; Goodbody-Gringley et al. 2010). Both natural (detached macroalgae, hydroids, and bryozoans) and artificial (buoys, pieces of wood or plastic, and ropes) floating substrata constitute ubiquitous dispersal agents for a wide diversity of organisms (Castilla and Guiñez 2000; Gutow et al. 2006). Many marine vertebrates such as whales, manatees, and sea turtles also provide a suitable substratum for the attachment of these epibionts (Caine 1986; Pfaller et al. 2008; Suárez-Morales et al. 2010), with some individuals supporting abundant and diverse epibiont communities. Furthermore, marine invertebrates and, in particular, crustacean species are able to disperse large distances as a part of the fouling communities of ships and boats (Cohen and Carlton 1998; Galil et al. 2002; Thiel et al. 2003).

Dispersal by rafting is a stochastic event, and it is difficult to quantify its significance in the marine environment (Thiel and Haye 2006). In many cases, single aspects of the life history such as reproductive mode and larval longevity have been successfully used as a surrogate for estimating dispersal ability and population connectivity (e.g. Lester and Ruttenberg 2005; Sherman et al. 2008). However, patterns in connectivity are difficult to predict based on reproductive traits alone and are likely strongly influenced by multiple biotic and abiotic environmental factors, especially oceanographic processes such as local water circulation patterns (Bowen et al. 2006; Nunes et al. 2011). In such situations, genetic analysis of population differentiation can provide a powerful tool for investigating dispersal (Teske et al. 2005; Thiel and Haye 2006; Goodbody-Gringley et al. 2010).

Some of the most common marine invertebrates reported rafting are peracarid crustaceans (amphipods, isopods, and tanaids) (Sano et al. 2003; Fraser et al. 2011; Xavier 2011). All peracarids have direct development and, in many species, females provide extended parental care for their offspring (Thiel 2003). These life history strategies can be advantageous because local populations with great number of individuals can be maintained on a floating item, facilitating settlement, and rapid colonisation of patches after a disturbance event (Thiel and Gutow 2005b). Caprellids are some of the most common motile amphipods found on rafts. They have been reported from a wide variety of floating substrata, from macroalgae to artificial floating items such as buoys (Thiel et al. 2003; Thiel and Gutow 2005b). Upon being detached, these substrata may be easily distributed over distances on the local (tens of $\mathrm{km}$ ) and regional (hundreds of $\mathrm{km}$ ) scale (Jara and Jaramillo 1979; Thiel et al. 2003; Thiel and Gutow 2005b). Indeed, Takeuchi and Sawamoto (1998) reported many caprellids from plankton samples in the western North Pacific, and they suggested that at least some of these could have reached the offshore waters clinging to floating items. Furthermore, Aoki and Asakura (1995) reported that the caprellid fauna found on the oceanic islands of Ogasawara may have colonised it from Japanese Islands or even the Asian mainland. The morphology of caprellids is well adapted to cling to diverse substrata, with reduced pleopods which are used for swimming in other amphipod crustaceans (Aoki and Kikuchi 1995; Guerra-García et al. 2002). This, as well as the lack of a planktonic larval stage, suggests that cosmopolitan distribution of many littoral caprellid species might be facilitated by often being associated with fouling communities on floating objects, which have a high potential for far-ranging dispersal (Thiel 2003).

More than 25 caprellid species have been reported or inferred as rafters (see Thiel and Gutow 2005b; Ashton 2006). They are all thought to be facultative rafters (i.e. that only occasionally occur on floating objects) with only one exception, the cosmopolitan species Caprella andreae Mayer, 1890, which is, to our knowledge, the only obligate rafter (i.e. that lives exclusively on rafts where spends its entire cycle) of the suborder Caprellidea (Ruffo 1993, Krapp-Schickel 1993). This species has been mainly reported to attach to floating objects, such as buoys and pieces of wood; however, it can also be found on the carapaces of Caretta caretta (Linnaeus, 1758) and Chelonia mydas (Linnaeus, 1758) (Krapp-Schickel 1993; Sezgin et al. 2009; Zakhama-Sraieb et al. 2010). Mayer (1890) described it as a variety of the complex Caprella acutifrons; however, it was given specific rank, and it is presently a valid species (McCain 1968; Cabezas et al. 2010). Caprella andreae differs from the other related species of the complex mainly in the convexity of the propodus of pereopods 5-7, which is probably an adaptation to strongly cling to drifting objects or tiny algae on the turtle carapace. In fact, Aoki and Kikuchi (1995) suggested that $C$. andreae may have speciated from the $C$. acutifrons by adapting to ecologically isolated habitats such as drifting objects.

Although rafting on macroalgae or artificial flotsam and turtle carapaces has been extensively reported in many marine invertebrates (e.g. Rawson et al. 2003; Torres-Pratts et al. 2009; Hoeksema et al. 2012; Xavier et al. 2012), the studies only focussing on caprellid amphipods have been carried out on a facultative rafter species (see Ashton 2006; 
Boos 2009). Therefore, the importance of rafting in the dispersal of an obligate rafter caprellid species has not been investigated. Furthermore, to our knowledge, no studies have been conducted in which the variability in chance and success of dispersion processes inherent to floating substrata have been taken into account.

The amphipod $C$. andreae is reported here, for the first time, in southern Mediterranean Spain, upon examination of the epifauna clinging to a drifting rope off the coast of El Morche (Málaga). This discovery prompted us to analyse the DNA sequence diversity of mitochondrial and nuclear markers of 52 specimens of $C$. andreae collected from different types of substrata, in seven locations across the North Atlantic and the Mediterranean regions, in search of patterns of genetic variation that could inform us about the role of both oceanic currents and behavioural traits on the dispersal capabilities and connectivity of this small crustacean rafter.

\section{Materials and methods}

Sample collection, DNA extraction and PCR amplification

During a sampling survey along the Andalusian coast, several specimens of the brooding cosmopolitan caprellid $C$. andreae, together with other fouling marine invertebrates, were discovered on a drifting rope in $150 \mathrm{~m}$ from the shore of El Morche, Málaga, Southern Spain (Figs. 1, 2; Table 1). Caprella andreae individuals were sorted in situ and preserved in absolute ethanol. The rope was kept in a plastic container and stored in $95 \%$ ethanol. In the laboratory, the volume, length, and thickness of the rope were estimated (approximately $1.6 \mathrm{~L}, 3.5$, and $0.02 \mathrm{~m}$, respectively), and the rest of the associated fauna was sorted and removed from the rope. All peracarid crustaceans were identified to species level and counted.
Fig. 1 Caprella andreae Mayer, 1890 from El Morche, Málaga, Southern Spain $\left(36^{\circ} 44^{\prime} 15^{\prime \prime} \mathrm{N}, 3^{\circ} 59^{\prime} 38^{\prime \prime} \mathrm{W}\right)$. a Drifting rope found in El Morche, floating at $150 \mathrm{~m}$ from the shore. In the smaller picture, the white arrow shows the presence of $C$. andreae.

b Lateral view of an adult male and female found on the rope. c Antenna 1 and antenna 2. Note the robustness of antenna 1. d Gnathopod 2. e Gills. Note the big size and round shape of them. f Pereopod 7, showing the convexity of the propodus palm. Scale bars $1 \mathrm{~mm}$ (colour figure online)
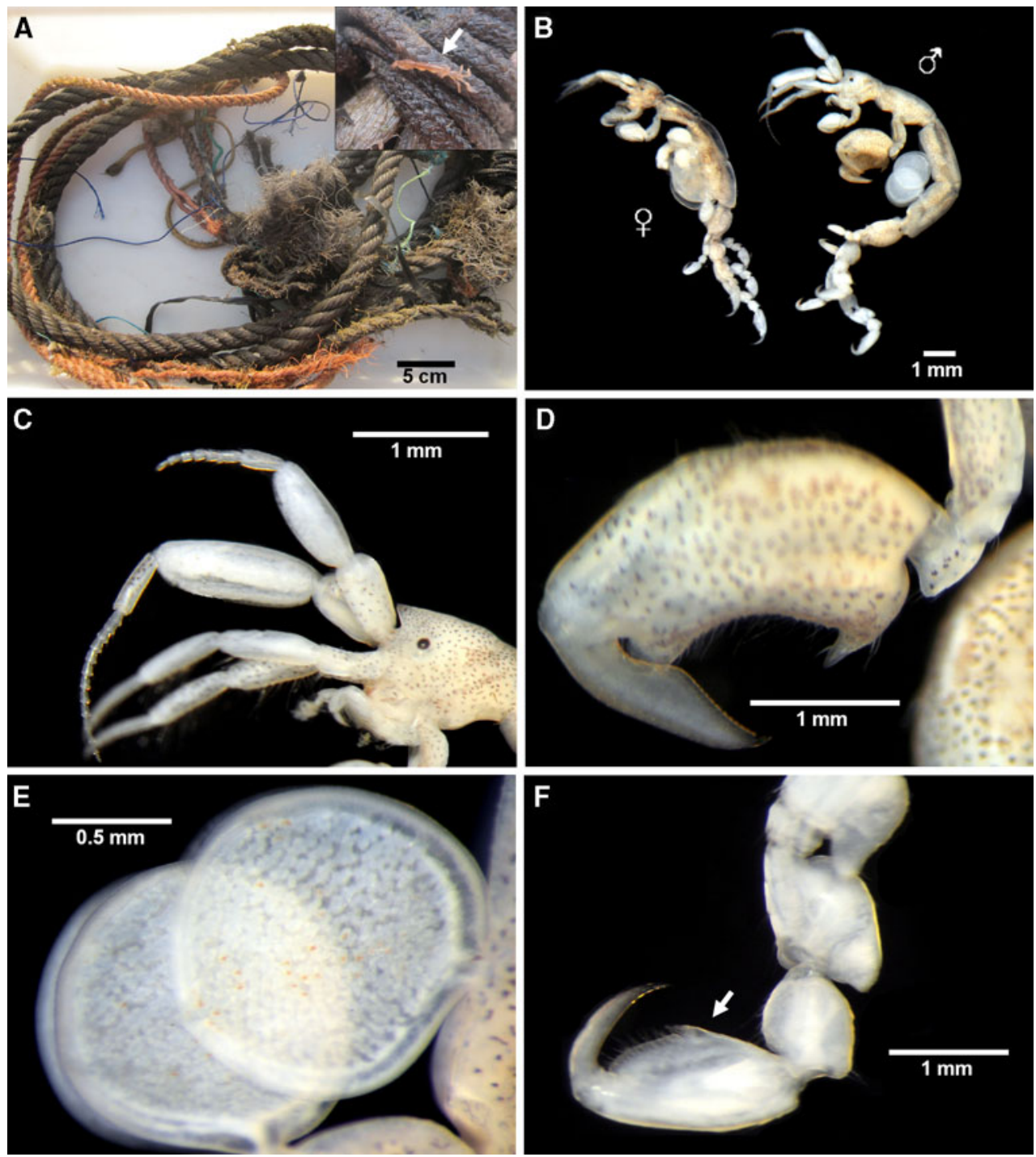


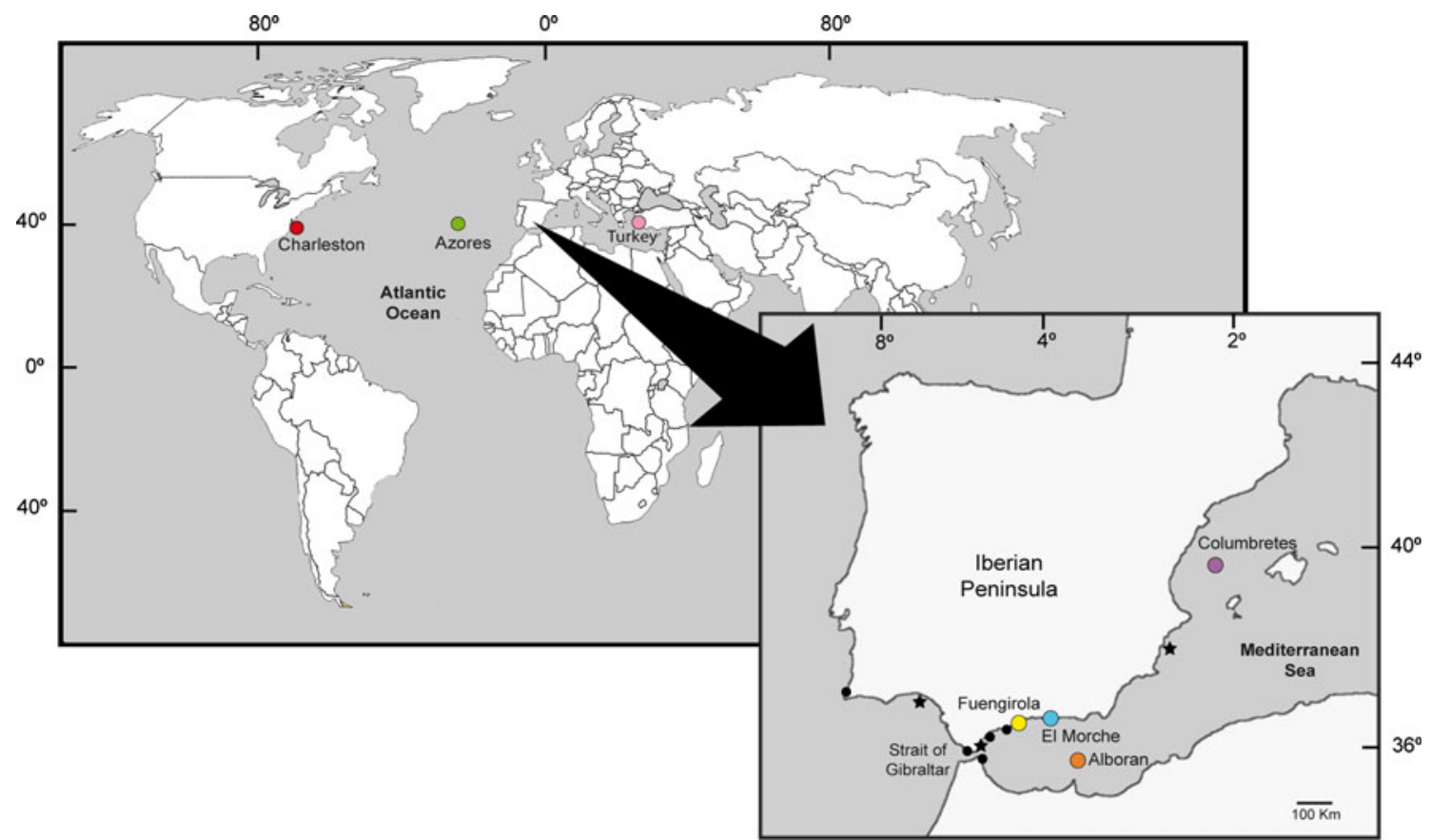

Fig. 2 Map showing sampling localities included in the present study. Each coloured circles represent sampling sites where C. andreae populations were collected. Those indicated by black

Regarding $C$. andreae specimens, the proportion of males, females (ovigerous and non-ovigerous), and juveniles was recorded, and the number of eggs per female was counted in those females with a closed brood pouch.

To explore genetic differentiation within this species, another six populations of $C$. andreae found on different floating substrata were included (Fig. 2; see also Table 1 for further details). To assess interspecific divergence, some populations of the close species Caprella penantis Leach, 1814 and Caprella dilatata Krøyer, 1843, also described by Mayer (1890) as forms of the 'C. acutifrons' group and later have been given specific rank (McCain 1968; Cabezas et al. 2010), were also sequenced (Table 1). Genomic DNA was extracted from legs, gnathopods, gills, and pereopods using the commercial kit Jetquick (Genomed). A region of the mitochondrial cytochrome $c$ oxidase subunit I (COI) gene was amplified by polymerase chain reaction (PCR). Because of reduced amplification success using universal primers (Folmer et al. 1994), Caprella genus-specific primers were designed using the software package Primer3 (Rozen and Skaletsky 2000). The sequences of the primers are Cp_COIF2 (5'-GGA GAT GAY CAA ATT TAT AAT G-3') and Cp_COIR1 (5'-AAT ATA YAC TTC TGG RTG ACC- $\left.3^{\prime}\right)$. PCR amplifications were done in a $25-\mu$ reaction volume containing a magnesium concentration of $3 \mathrm{mM}$ under the following conditions: initial 4-min denaturation at $94{ }^{\circ} \mathrm{C}$, followed by 40 cycles of $45 \mathrm{~s}$ at $94{ }^{\circ} \mathrm{C}, 50 \mathrm{~s}$ at $45^{\circ} \mathrm{C}$, and $1 \mathrm{~min}$ at $72{ }^{\circ} \mathrm{C}$. Final extension was achieved at circles and black stars correspond to localities where the close species $C$. penantis and $C$. dilatata, respectively, were taken. See Table 1 for further details of each population (colour figure online)

$72{ }^{\circ} \mathrm{C}$ for $10 \mathrm{~min}$. Platinum Taq (Invitrogen, Carlsbad, California, USA) was used for all PCR amplifications. Additionally, a 1,051 base pairs (bp) fragment of the nuclear $18 \mathrm{~S}$ ribosomal RNA (rRNA) was obtained for nine individuals belonging to $C$. andreae, using primers $18 \mathrm{~S}$-ai and 18S-bi described by Whiting (2002). The number of individuals analysed for the nuclear gene fragment is a subset of that used for the mtDNA due to the difficulties in obtaining good amplicons and respective sequencing data from all sampled individuals. Three individuals were from El Morche (CAMOR), three from Azores (CAAZO), and three individuals from a highly divergent COI lineage (see Results) from Charleston (CACHA). Again, some C. penantis and C. dilatata individuals were also sequenced. PCR amplifications were achieved using $2 \mathrm{mM}$ of $\mathrm{MgCl}_{2}$, under the following conditions: initial 4-min denaturation at $94{ }^{\circ} \mathrm{C}$, followed by 35 cycles of $45 \mathrm{~s}$ at $94{ }^{\circ} \mathrm{C}, 45 \mathrm{~s}$ at $56-60{ }^{\circ} \mathrm{C}$, and $1 \mathrm{~min}$ at $72{ }^{\circ} \mathrm{C}$. Final extension was achieved at $72{ }^{\circ} \mathrm{C}$ for $12 \mathrm{~min}$.

PCR product purification and sequencing were provided by a commercial company (High-Throughput Genomics Unit-HTGU, Department of Genome Sciences of the University of Washington).

\section{Estimates of genetic diversity}

Sequences were checked and edited using Sequencher program (Genes Codes Corporation, Ann Arbor, Michigan, 
Table 1 List of species sequenced, including populations codes, sampling localities with respective geographical coordinates and substrata where they were taken

\begin{tabular}{|c|c|c|c|c|c|}
\hline Species & Code & Locality & Coordinates & Substrates & Accession nos. forCOI, $18 \mathrm{~S}$ \\
\hline \multirow[t]{7}{*}{ C. andreae } & CAMOR & El Morche (Málaga) Spain & $36^{\circ} 44^{\prime} 15^{\prime \prime} \mathrm{N}, 3^{\circ} 59^{\prime} 38^{\prime \prime} \mathrm{W}$ & Drifting rope & $\begin{array}{l}\text { JX988565-JX988579, } \\
\text { JX988596-JX988598 }\end{array}$ \\
\hline & CAAZO & São Miguel (Azores), Portugal & $37^{\circ} 48^{\prime} 28^{\prime \prime} \mathrm{N}, 23^{\circ} 33^{\prime} 80^{\prime \prime} \mathrm{W}$ & Drifting stick & $\begin{array}{l}\text { JX988539-JX988552, } \\
\text { JX988590-JX988592 }\end{array}$ \\
\hline & CACOL & $\begin{array}{l}\text { Columbretes (Castellón), } \\
\text { Spain }\end{array}$ & $39^{\circ} 51^{\prime} 19.2^{\prime \prime} \mathrm{N}, 0^{\circ} 40^{\prime} 04.2^{\prime \prime} \mathrm{E}$ & Drifting material & JX988557-JX988558 \\
\hline & CAALB & Alboran Sea, Spain & $35^{\circ} 56^{\prime} 26.35^{\prime \prime} \mathrm{N}, 3^{\circ} 1^{\prime} 23.91^{\prime \prime} \mathrm{W}$ & Caretta caretta (turtle) & JX988531-JX988538 \\
\hline & CAFUE & Fuengirola (Málaga), Spain & $36^{\circ} 33^{\prime} 14.37^{\prime \prime} \mathrm{N}, 4^{\circ} 29^{\prime} 21.39^{\prime \prime} \mathrm{W}$ & Caretta caretta (turtle) & JX988559-JX988564 \\
\hline & CATUR & Seferihisar (Izmir), Turkey & $38^{\circ} 11^{\prime} 32^{\prime \prime} \mathrm{N}, 26^{\circ} 38^{\prime} 07^{\prime \prime} \mathrm{E}$ & Caretta caretta (turtle) & JX988580-JX988582 \\
\hline & CACHA & Charleston (Florida), USA & $28^{\circ} 23^{\prime} 14.6^{\prime \prime} \mathrm{N}, 80^{\circ} 32^{\prime} 38.8^{\prime \prime} \mathrm{W}$ & Caretta caretta (turtle) & $\begin{array}{l}\text { JX988553-JX988556, } \\
\text { JX988593-JX988595 }\end{array}$ \\
\hline \multirow[t]{4}{*}{ C. penantis } & CPTAR & Tarifa Island (Cádiz), Spain & $36^{\circ} 00^{\prime} 00.7^{\prime \prime} \mathrm{N}, 5^{\circ} 36^{\prime} 37.5^{\prime \prime} \mathrm{W}$ & Intertidal alga Asparagopsis armata & JX988583, JX988599 \\
\hline & CPEST & Estepona (Málaga), Spain & $36^{\circ} 25^{\prime} 28.79^{\prime \prime} \mathrm{N}, 5^{\circ} 8^{\prime} 41.51^{\prime \prime} \mathrm{W}$ & Intertidal alga Corallina elongata & JX988584, JX988600 \\
\hline & CPCAST & Castelejo, Portugal & $37^{\circ} 06^{\prime} 9.3^{\prime \prime} \mathrm{N}, 8^{\circ} 56^{\prime} 46.7^{\prime \prime} \mathrm{W}$ & Intertidal alga Gelidium sp. & JX988585, JX988601 \\
\hline & CPALM & Punta Almina (Ceuta), Spain & $35^{\circ} 54^{\prime} 2.52^{\prime \prime} \mathrm{N}, 5^{\circ} 16^{\prime} 29.68^{\prime \prime} \mathrm{W}$ & $\begin{array}{l}\text { Intertidal alga Gelidium } \\
\text { sesquipedale }\end{array}$ & JX988586 \\
\hline \multirow[t]{3}{*}{ C. dilatata } & CDALI & Guardamar (Alicante), Spain & $38^{\circ} 05^{\prime} 1.10^{\prime \prime} \mathrm{N}, 0^{\circ} 38^{\prime} 1.59^{\prime \prime} \mathrm{W}$ & Fish farm & JX988587, JX988602 \\
\hline & CDALG & Algeciras Bay (Cádiz), Spain & $36^{\circ} 10^{\prime} 0.5^{\prime \prime} \mathrm{N}, 5^{\circ} 24^{\prime} 36.82^{\prime \prime} \mathrm{W}$ & On buoys (algae and bryozoans) & JX988588 \\
\hline & CDPOR & El Portil (Huelva), Spain & $37^{\circ} 12^{\prime} 43^{\prime \prime} \mathrm{N}, 7^{\circ} 4^{\prime} 26.80^{\prime \prime} \mathrm{W}$ & On buoys (algae and bryozoans) & JX988589, JX988603 \\
\hline
\end{tabular}

The last column depicts GenBank accession numbers

USA). They were confirmed as Caprellidea DNA using GenBank $^{\mathrm{TM}}$ BLASTn searches.

For COI gene, all sequences were aligned using ClustalW (Thompson et al. 1994) as implemented in BioEdit (Hall 1999) and trimmed to $546 \mathrm{bp}$ for the final alignment. Sequences were uploaded in DnaSP (Librado and Rozas 2009) and translated into aminoacids to confirm the integrity of the sequenced genes and discard the presence of pseudogenes. Uncorrected $p$-distances were calculated in MEGA version 5.05 (Tamura et al. 2011) and were used to estimate genetic divergence between pairs of taxa. Measures of genetic diversity, haplotype diversity $(H d)$, and nucleotide diversity $(\pi)$ were estimated for each locality, using Arlequin version 3.5 (Excoffier and Lischer 2010). Localities with less than four individuals, Turkey

Table 2 Estimates of genetic diversity for the mtDNA COI gene of C. andreae for each sampling site

\begin{tabular}{lrlll}
\hline Papulations & $N$ & $H$ & $H d$ & $\pi$ \\
\hline CAMOR & 15 & 2 & 0.133 & 0.0005 \\
CAAZO & 14 & 4 & 0.396 & 0.0016 \\
CACOL & 2 & 1 & - & - \\
CAALB & 8 & 4 & 0.750 & 0.0131 \\
CAFUE & 6 & 4 & 0.800 & 0.0051 \\
CATUR & 3 & 1 & - & - \\
CACHA & 4 & 2 & 0.500 & 0.0027 \\
\hline
\end{tabular}

$N$ number of individuals, $H$ number of haplotypes, $H d$ haplotype diversity, $\pi$ nucleotide diversity
(CATUR) and Columbretes (CACOL) (see Table 2), were excluded from the analyses.

Sequences of $18 \mathrm{~S}$ rRNA were aligned using the MAFFT algorithm (Katoh et al. 2005), and highly variable regions were eliminated from the analysis using Gblocks (Castresana 2000). Uncorrected $p$-distances between taxa were also calculated in MEGA version 5.05 (Tamura et al. 2011).

Population structure and isolation by distance estimates

Estimates of population differentiation were obtained from pairwise $F_{\mathrm{ST}}$ calculations for the mitochondrial dataset using pairwise differences as a distance measure, except when the number of individuals sampled per locality was less than four. Statistical significance was assessed through 10,000 permutations. All estimates and respective significance were obtained using Arlequin version 3.5 (Excoffier and Lischer 2010).

Isolation by distance was tested on the mitochondrial dataset using a non-parametric Mantel test as incorporated in the IBDWS version 3.15 (Jensen et al. 2005), using $F_{\text {ST }}$ genetic and geographical distances (calculated as the approximate linear distance along shoreline) between population pairs and 30,000 randomisations.

Phylogenetic analyses

Phylogenetic analyses of the COI dataset were conducted using the maximum parsimony (MP), maximum likelihood 
(ML), and Bayesian inference (BI) methods. Only one individual (or sequence) per variant haplotype was included.

To test the occurrence of saturation, uncorrected $p$-distance values between haplotypes were plotted against maximum likelihood distance. ML distances were obtained using the parameters of the evolutionary model co-estimated with the ML tree.

The MP analysis was performed with MEGA version 5.05 (Tamura et al. 2011), using 1,000 bootstraps analyses to estimate branch support. The software jModelTest 0.1 (Posada 2008) was used to search for the most appropriate model of evolution using the Akaike information criterion (AIC) for our dataset. The HKY + I + G model was found to be the best-fit model for the data. The ML tree was reconstructed using the software package PhyML (Guindon et al. 2010). Branch support was inferred by 1,000 bootstraps. Bayesian phylogenetic analyses were performed with the program MrBayes version 3.1.2 (Ronquist and Huelsenbeck 2003). Two independent runs were conducted with $3 \times 10^{7}$ generations each. Parameters were sampled every 1,000 generations with the heating parameter set to 0.1 . Majority-rule consensus trees were estimated combining results from duplicated analyses, using a burnin of $10 \%$. Adequate burnin was tested using the software Tracer version 1.5 (Rambaut and Drummond 2007). The phylogenetic relationships among Caprellidea are poorly understood, making the selection of an appropriate outgroup difficult. However, recent molecular analyses carried out by Ito et al. (2011) based on the 18S ribosomal RNA gene have indicated that there is a close relationship between Cyamidae (another family belonging to suborder Caprellidea) and Caprellidae. Therefore, the COI gene sequence from one Cyamidae species, Cyamus ovalis Roussel de Vauzème, 1834, obtained from GenBank (accession no. DQ094901.1), was selected as outgroup. Furthermore, five other Caprella species were included in the analyses (Caprella septentrionalis Krøyer, 1838: FJ581589.1; Caprella linearis (Linnaeus, 1767): FJ581571.1; Caprella mutica Schurin, 1935: FJ581578.1; Caprella scaura Templeton, 1836: AB539699.1; and Caprellidae sp.: EF989681.1).

Haplotype genealogy was also investigated by building a network of haplotypes using TCS version 1.21 (Clement et al. 2000) with a $90 \%$ statistical parsimony connection limit. All sequences were deposited in GenBank (accession numbers: JX988531-JX988603).

\section{Results}

Abundance and diversity of epibiont community

A total of 517 specimens of $C$. andreae were found attached to the rope, including 67 males, 109 females (29 ovigerous), and 341 juveniles. The number of eggs per female was $16.9 \pm 5.7$ (Mean \pm SD) with a range 10-29. No intraspecific morphological variation was observed between this population and the others $C$. andreae populations considered in this study (Fig. 1). Furthermore, these abundance measures are in accordance with what was previously described by Mayer (1890) for populations of $C$. andreae from the Atlantic coast of United States. Together with C. andreae, another six epibiont species were recorded. In addition to an abundant population of the gooseneck barnacle Lepas anatifera Linnaeus, 1758, several peracarids were also found: the isopod Idotea metallica Bosc, 1802 (121 specimens); the gammarids Jassa cadetta Krapp, Rampin and Libertini, 2008 (2319 specimens), Elasmopus brasiliensis (Dana, 1855) (2 specimens) and Hyale grimaldii Chevreux, 1891 (1 specimen), and the caprellid Caprella hirsuta Mayer, 1890 (1 specimen). The most abundant peracarid species were the gammarid $J$. cadetta, the caprellid C. andreae, and the isopod I. metallica.

\section{Estimates of genetic diversity}

The COI sequence dataset obtained for $C$. andreae, including the close species $C$. penantis and $C$. dilatata, after alignment, consisted of $546 \mathrm{bp}$. The COI gene was amplified for $52 C$. andreae individuals and for four and three $C$. penantis and $C$. dilatata populations, respectively (see Tables 1,2). A total of 221 variable sites were found, of which 182 were parsimony informative including outgroup species. A total of 17 haplotypes were observed. Most of the localities sampled showed unique haplotypes, of which ten were singletons. Only one haplotype (h1) was shared by two localities in Mediterranean Sea: Alboran and Fuengirola. When sequences were translated into proteins no stop codons were detected, so there was no reason to believe that these results came from a nuclear pseudogene.

For the mtDNA COI gene, overall, both haplotype $(H d=0.842)$ and nucleotide $(\pi=0.036)$ diversities were high. Haplotype diversity ranged from 0.133 in $C$. andreae from $\mathrm{El}$ Morche (CAMOR) to 0.800 in population from Fuengirola (CAFUE) (Table 2). Nucleotide diversity ranged from 0.0005 in CAMOR to 0.0131 in population from Alboran (CAALB). Interestingly, populations collected from turtle carapaces (CAALB, CAFUE and CACHA) depicted higher values of genetic diversity than populations found on floating objects such as a stick or a rope (CAAZO and CAMOR, respectively) (Table 2).

Genetic differentiation calculated from the alignment of the mtDNA COI gene revealed two highly divergent groups in $C$. andreae: one including populations from the eastern Atlantic and western Mediterranean (Spain and Portugal populations, $C_{\mathrm{A}}$ ) and the other where populations from western Atlantic and eastern Mediterranean (Charleston and 
Table 3 Average uncorrected sequence divergence (\%) between major mitochondrial COI (lower diagonal) and nuclear 18S (upper diagonal) clades

\begin{tabular}{|c|c|c|c|c|}
\hline & $\begin{array}{l}\text { Clade } \\
A\left(C_{A}\right)\end{array}$ & $\begin{array}{l}\text { Clade } \\
B\left(C_{B}\right)\end{array}$ & $\begin{array}{l}\text { C. } \\
\text { penantis }\end{array}$ & $\begin{array}{l}\text { C. } \\
\text { dilatata }\end{array}$ \\
\hline $\begin{array}{c}\text { Clade A } \\
\left(C_{\mathrm{A}}\right)\end{array}$ & - & 0.9 & 0.4 & 0.7 \\
\hline $\begin{array}{c}\text { Clade B } \\
\left(C_{\mathrm{B}}\right)\end{array}$ & 14.0 & - & 0.4 & 0.7 \\
\hline C. penantis & 14.6 & 14.8 & - & 0.6 \\
\hline C. dilatata & 11.0 & 13.7 & 12.9 & - \\
\hline
\end{tabular}

Turkey, respectively) were included $\left(C_{\mathrm{B}}\right)$. Uncorrected COI genetic divergence between $C_{\mathrm{A}}$ and $C_{\mathrm{B}}$ was in the range of $12.95-15.5 \%$ (Table 3). Within Clade $C_{\mathrm{A}}$, levels of divergence ranged from 0.2 to $4.4 \%$. However, despite the longer geographic distances, uncorrected $p$-distances within Clade $C_{\mathrm{B}}$ were much lower (in the range of $0-0.6 \%$ ) than those obtained for $C_{\mathrm{A}}$. Divergence between population from Charleston and Turkey was on an average $3 \%$. For COI, $C_{\mathrm{A}}$ and $C_{\mathrm{B}}$ were estimated to be $14-15.7 \%$ and $14.5-15.3 \%$ divergent from C. penantis, respectively; and 10.3-12.2\% and $12.9-14.5 \%$ divergent from $C$. dilatata, respectively. Divergence between $C$. penantis and $C$. dilatata was approximately $13 \%$ (Table 3 ). Interspecific divergence within all Caprella species considered in this study (C. linearis, C. mutica, C. septentrionalis, C. scaura, Caprellidae sp., $C$. penantis, $C$. dilatata, and $C$. andreae) was on an average $18 \%$ (ranging from 12.7 to $22.1 \%$ ).

An alignment, including 1,051 bp, was obtained for the $18 \mathrm{~S}$ ribosomal gene, but only $904 \mathrm{bp}$ were considered to be reliably alignable using the software Gblocks. This nuclear gene also confirms the existence of the two divergent lineages $\left(C_{\mathrm{A}}\right.$ and $\left.C_{\mathrm{B}}\right)$, which showed a genetic divergence of $0.9 \%$. Divergence found between both $C_{\mathrm{A}}$ and $C_{\mathrm{B}}$, and $C$. penantis and C. dilatata was of $0.4 \%$ and $0.6-0.8 \%$, respectively; and between $C$. penantis and $C$. dilatata was in the range $0.3-0.8 \%$ for the $18 \mathrm{~S}$ gene (Table 3 ).

Population differentiation and isolation by distance estimates

Most of the pairwise $F_{\mathrm{ST}}$ values were high, revealing high levels of differentiation between localities. The only exception was between Alboran (CAALB) and Fuengirola (CAFUE) that showed the lowest level of differentiation $\left(F_{\mathrm{ST}}<0.1\right)$ (Table 4$)$. Most pairwise $F_{\mathrm{ST}}$ values were significantly different from zero. Only CAALB and CAFUE displayed non-significant $F_{\mathrm{ST}}$ values, so these can be considered as samples from the same population. Values of $F_{\mathrm{ST}}$ ranged from 0.078 (CAALB-CAFUE) to 0.994 (CACHA-CAMOR) (Table 4).
Table 4 Pairwise $F_{\mathrm{ST}}$ values between populations of $C$. andreae based on mtDNA COI sequences

\begin{tabular}{lllll}
\hline & CAALB & CAAZO & CACHA & CAFUE \\
\hline CAAZO & $0.627^{*}$ & & & \\
CACHA & $0.928^{*}$ & $0.987^{*}$ & & \\
CAFUE & 0.078 & $0.738^{*}$ & $0.969^{*}$ & \\
CAMOR & $0.774 *$ & $0.964^{*}$ & $0.994^{*}$ & $0.937^{*}$ \\
\hline
\end{tabular}

Statistical significance was obtained through 10,000 permutations $* P<0.05$

Results from isolation by distance test showed no significant correlation between genetic distance and geographic distance $\left(r^{2}=0.218\right.$, one-sided $\left.p=0.218\right)$, rejecting a pattern of isolation by distance for the COI dataset.

Phylogenetic analysis

Overall, MP, ML, and BI analyses of the COI dataset rendered trees with very similar topologies, differing only in the position of a few haplotypes within inner groups (Fig. 3). Caprella andreae was found to be paraphyletic in all analyses (including the $18 \mathrm{~S}$, Table 3 ). The phylogenetic trees were characterised by four major clades (excluding the outgroups) all of which had moderate to relatively high bootstrap support. A first clade (Clade A) contained all C. andreae haplotypes from eastern Atlantic and western Mediterranean and corresponds to $C_{\mathrm{A}}$. Within this clade, some degree of substructuring was apparent, with haplotypes from the Azores (CAAZO), excluding CAAZO6, constituting a highly supported group by ML and BI analyses; the other nodes within this clade lack a relevant statistical support. The second and third clades included all $C$. dilatata and $C$. penantis haplotypes, respectively. A fourth highly supported clade contained all haplotypes of C. andreae from Charleston and Turkey (western Atlantic and eastern Mediterranean) corresponding to $C_{\mathrm{B}}$. Within this clade, two highly supported clades $(100 \%)$ were recovered: one composed of the western Atlantic haplotypes (Charleston) and another containing the haplotype from Turkey (eastern Mediterranean) (Fig. 3). Therefore, according to these phylogenetic trees, the two clades $\left(C_{\mathrm{A}}\right.$ and $\left.C_{\mathrm{B}}\right)$ containing the haplotypes from specimens identified as $C$. andreae are not closely related.

The haplotype analysis retrieved four independent networks that could not be connected using the $90 \%$ parsimony connection limit: (1) C. penantis, (2) C. dilatata, (3) $C$. andreae from Turkey and Charleston (clade $C_{\mathrm{B}}$ in the phylogenetic tree), and (4) $C$. andreae from eastern Atlantic and western Mediterranean (clade $C_{\mathrm{A}}$ in the phylogenetic tree) (Fig. 4). In the last case, a total of 14 haplotypes were observed for the 45 individuals considered. Only one haplotype, one of the most frequent, was shared 
Fig. 3 Bayesian consensus tree of the mtDNA COI gene. The tree was rooted with Caprella linearis (FJ581571.1), Caprella mutica (FJ581578.1), Caprella septentrionalis (FJ581589.1), Caprella scaura (AB539699.1), Caprellidae sp. (EF989681.1), and Cyamus ovalis (DQ094901.1), sequences available in GenBank. Bootstrap values of nodes correspond to maximum parsimony, maximum likelihood (both above branches), and to Bayesian posterior probabilities (below branches), respectively (n.s. indicates less than $50 \%$ support). See Table 1 for population codes

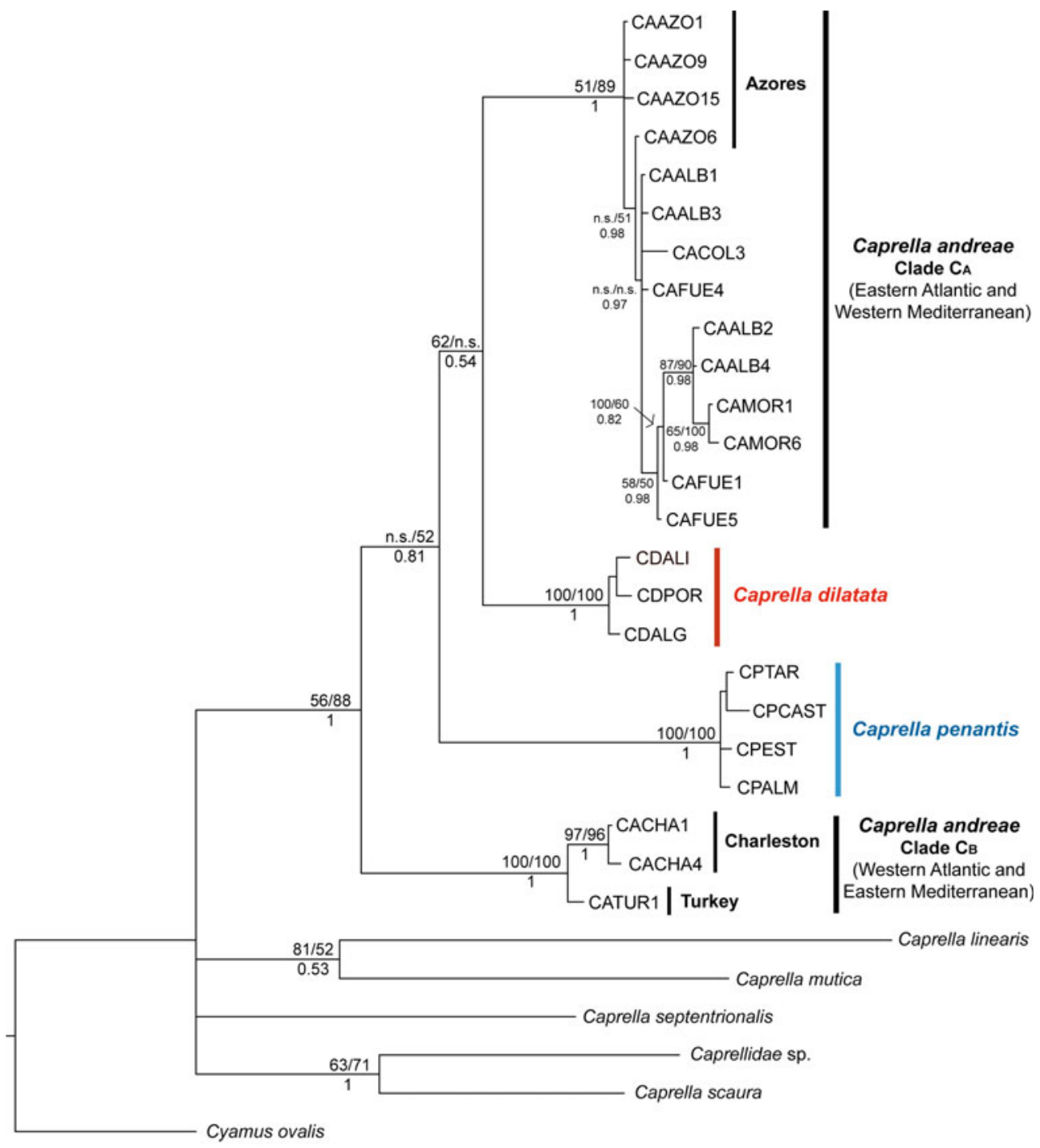

0.08 between two localities, corresponding to Fuengirola and Alboran (Fig. 4). Differences between haplotypes from different sampled localities were on the order of one to seven mutations (Fig. 4a). Haplotype network of the seven individuals of $C$. andreae from Turkey and Charleston was characterised by three haplotypes, which differs in fourteen mutations (Fig. 4b).

\section{Discussion}

The well-adapted nature of $C$. andreae to cling to floating substrata (e.g. Caine 1978; Takeuchi and Hirano 1995) and the fact that this species is an obligate rafter, which is also supported by this study, confirm that dispersal by rafting is of great importance to $C$. andreae and that the wide distribution of this brooding species can only be explained by this mechanism. In this study, the first record of C. andreae in Southern Mediterranean Spain is reported. The strong genetic differentiation with no mtDNA haplotypes shared between populations may suggest that $C$. andreae is quite faithful to the substratum on which it settles. In addition, the proportionally higher genetic diversity displayed in $C$. andreae populations living on turtles as well as the presence of highly differentiated haplotypes in the same turtle population may be indicative that it can survive longer on them and, therefore, it could prefer turtles instead of floating objects to settle and disperse. The results of this study also suggest that specimens identified as C. andreae most probably represent at least two different species. This discovery prompts for a more detailed phylogenetic analysis and taxonomic revision of genus Caprella. 
A1

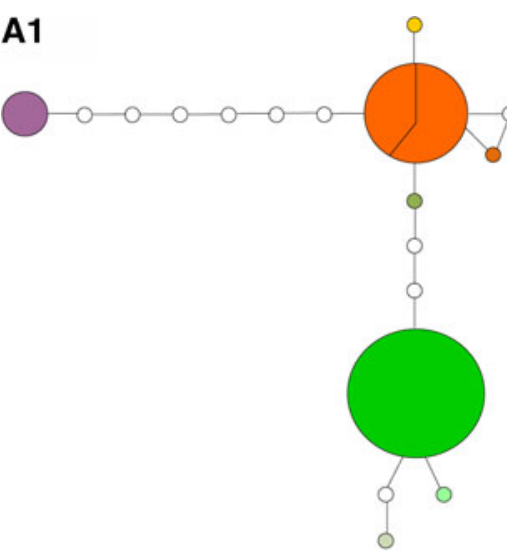

A2

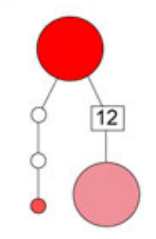

-1 mutation

B
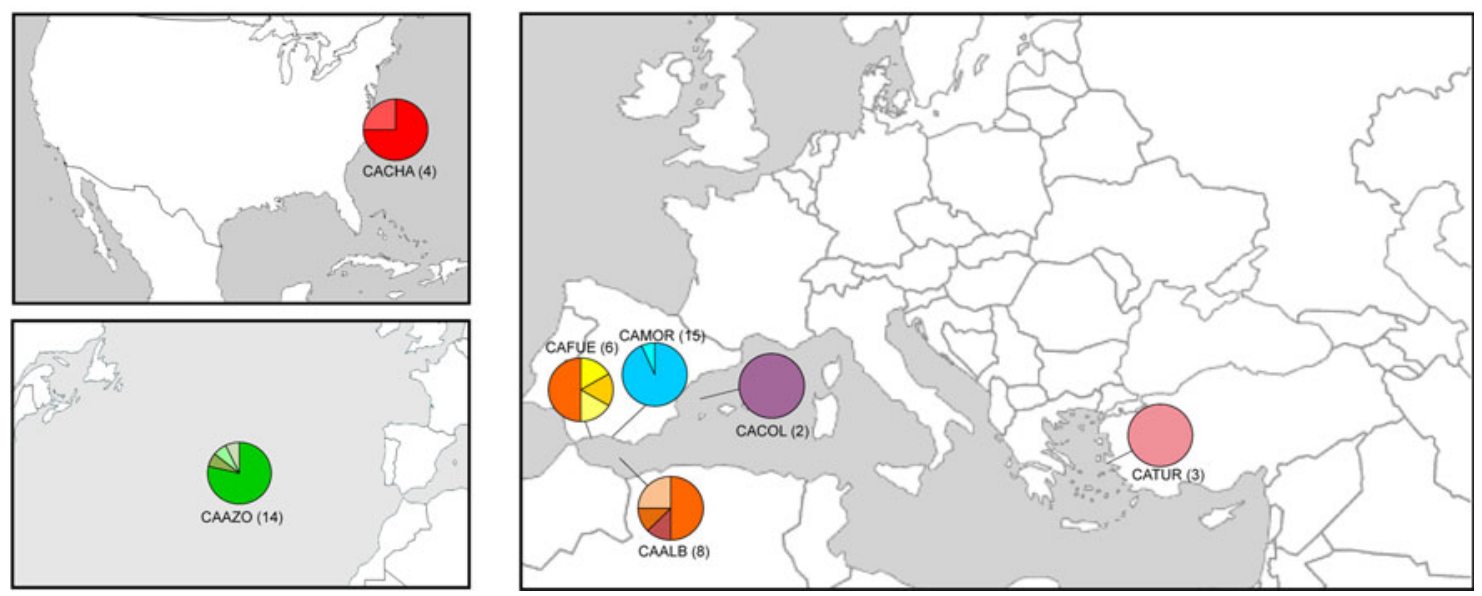

Fig. 4 a Mitochondrial (COI) haplotypes network (90\% parsimony connection limit) of $C$. andreae. a1 C. andreae's haplotypes from eastern Atlantic and western Mediterranean (clade $C_{\mathrm{A}}$ in the phylogenetic tree; Fig. 3). a2 C. andreae's haplotypes from Turkey and Charleston (corresponding to clade $C_{\mathrm{B}}$ in the phylogenetic tree; Fig. 3). Circle sizes are proportional to haplotype frequency, and each circle is colour coded according to the haplotype's presence in sampling locations (see Figs. 2, 4b). Non-observed haplotypes are

\section{Geographical origin of the raft}

Understanding the ecology, general distribution and diversity of the epibiont community that dwells drifting material will help to clarify certain questions about the origin of the substrata or their possible movements during its dispersion courses. During this study, seven crustacean species were reported on a drifting rope. The most commonly occurring epibionts were the caprellid species C. andreae, the isopod Idotea metallica and the gammarid $J$. cadetta. The taxonomy of the genus Jassa has been traditionally confusing (Conlan 1990). Although our specimens resemble the recently described species J. cadetta (Krapp-Schickel et al. 2008), they also share some characteristics with Jassa slatteryi Conlan, 1990. As a result, further taxonomical revision of the material, including a molecular approach, would be useful in represented by small white circles. Each line connecting haplotypes represents a single mutational change, as well as the number on the box. b Geographical distribution of the 17 COI haplotypes of C. andreae in the Mediterranean Sea and the Atlantic Ocean. Each site is represented by a pie chart showing population composition and relative haplotypes frequency. Site codes correspond to Table 1, numbers in parentheses indicate sample size (colour figure online)

clarifying the taxonomical status of our specimens. Most of these species found on the rope have cosmopolitan or Atlanto-Mediterranean distributions (Van der Baan and Holthuis 1969; Ruffo 1993), except for C. hirsuta and $J$. cadetta, which are considered Mediterranean endemics (Krapp-Schickel 1993; Krapp-Schickel et al. 2008, 2011). Therefore, their presence suggest that this artificial substratum is either of Mediterranean origin or has remained in this area long enough to be colonised.

Only $2 \%$ of world amphipods are obligate rafters; most of them are facultative (see Thiel and Gutow 2005b). Regarding this study, only $C$. andreae, Hyale grimaldii (Mcgrath and Myers 1989; Ruffo 1993; Zakhama-Sraieb et al. 2010), and I. metallica are obligate rafters that have been reported to be found exclusively on floating objects (Butler 1975; Gutow and Franke 2003; Sano et al. 2003), and all previous records of C. hirsuta, E. brasiliensis, and 
J. cadetta are from attached substrata (e.g. algae, hydroids) (Karaman 1982; Krapp-Schickel 1993; Guerra-García et al. 2000; Krapp-Schickel et al. 2011). Consequently, this study represents the first record of these last three species on floating items, indicating that these species are facultative rafters.

Caprella andreae was described from the Atlantic coast of the USA $\left(38^{\circ} 10^{\prime} \mathrm{N}, 64^{\circ} 20^{\prime} \mathrm{W}\right)$. Later, this species has been reported to be found in several areas around the world: North Sea, The Netherlands, Belgium, Portugal, Azores, Turkey, Gulf of Lion and St. Raphael (France), Naples (Italy), Aegean Sea, Algeria, off Casablanca (Morocco), New Jersey, Cape Hatteras and Beaufort, North Carolina, Florida (USA), Havana (Cuba), Sea of Japan, Korean Strait, and West coast of Kyushu (Japan) (McCain 1968; Krapp-Schickel 1993; Sezgin et al. 2009; ZakhamaSraieb et al. 2010). This study represents the first record of C. andreae in Southern Mediterranean Spain. During an extensive survey of caprellids associated with algae along the whole of the Iberian Peninsula and North Africa (Guerra-García 2001; Guerra-García et al. 2010), $C$. andreae was never found attached to fixed natural substrata of the benthic communities, confirming that this species seems to be adapted to living exclusively as an integral member of the permanent rafting community. A few records of $C$. andreae on fixed natural substrata exist (e.g. Prato and Biandolino 2005; Pereira et al. 2006), but these could be misidentifications or confusions with morphologically similar species such as $C$. dilatata or C. penantis (Guerra-García et al. 2010).

\section{Evidences for long-distance dispersal by rafting}

Natural dispersal by rafting is seen as a successful longdistance dispersal mechanism, in particular, for species with direct development (Castilla and Guiñez 2000; Colson and Hughes 2004; Thiel and Gutow 2005b). The lack of correlation between genetic and geographic distances obtained among $C$. andreae populations associated with drifting items may be an indication that dispersal over vast distances is common in this species (Colson and Hughes 2004). Such a pattern was expected because Caretta caretta (Linnaeus 1758) turtle is a highly migratory species, with individuals capable of migrations spanning thousands of kilometres (Carr 1987; Bolten et al. 1998).

To date, $C$. andreae has only been found attached to diverse floating objects in the high sea. Although some of them may derive from the sea, the piece of rope where $C$. andreae was found in the present study probably belonged to a ship, and the contribution of human activities in the long-distance dispersal of this species cannot be ruled out. Human-mediated transport provides environmentally suitable conditions for rafters, and over very great distances, this may be a far more important method of dispersal than natural methods (Carlton 1987). In marine systems, international shipping (including ballast water and hull fouling) and aquaculture practices are considered the main anthropogenic vectors responsible for species movements across the oceans (Galil et al. 2002; Gollasch 2002; Ashton 2006). Dispersal mechanisms of caprellid species include mainly rafting (both natural and artificial substrata) (Caine 1980). They have been found to survive transport in ballast tanks (Carlton 1985) as well as dispersing over large distances as part of the fouling communities of sea-going vessels (Thiel et al. 2003; Astudillo et al. 2009). In fact, the global distribution and introduction pathways of some invasive caprellid species can be attributed to these vectors (Caprella californica: AMBS 2002; Caprella mutica: Takeuchi and Sawamoto 1998; Ashton 2006; Ashton et al. 2008; Caprella scaura: Krapp-Schickel et al. 2006; Martínez and Adarraga 2008; Guerra-García et al. 2011). Therefore, rafting on vessels, providing frequent opportunities for long-distance dispersal, is likely to be an important anthropogenic dispersal mechanism in $C$. andreae, which may also account for its wide geographic distribution.

Dispersal by rafting is considered as an important means of maintaining population connectivity on both small and large spatial scales: marine organisms that use rafting for dispersing can maintain large and relatively homogeneous populations with little or no genetic subdivision (Fraser et al. 2011; Hoeksema et al. 2012; Xavier et al. 2012). However, some studies have shown that rafting facilitates dispersal, but does not necessarily maintain genetic connectivity among distant populations (Waters and Roy 2004; Baratti et al. 2005; Waters 2011). In this study, high levels of genetic differentiation with almost no mtDNA haplotypes shared among locations were observed, which indicates low genetic exchange among these populations. These results may be a consequence of the small sample size considered in our study. So, to provide more assertive conclusions regarding the generality of the dispersal hypothesis presented in this paper, a more exhaustive geographic sampling with larger sampling sizes is needed. Additionally, data from several rafts per bay are necessary in order to assess genetic exchange on a smaller scale to check if caprellids are really limited to a single raft (see below) or is it just that there is limited exchange across the long distances among the sampling sites considered in the present study. On the other hand, several studies have revealed that behavioural traits and environmental features can have a strong effect on the genetic connectivity of marine populations (Thiel and Haye 2006; Richards et al. 2007; David et al. 2010). Regarding this study, there could be two main factors prone to maintain this kind of geographical structure: the predominant patterns of water circulation typical from this region and the behavioural traits 
of $C$. andreae with respect to the substratum on which it settles.

Unlike turtles, dispersal patterns of floating objects, such as ropes or driftwood, depend mostly on ocean currents (Thiel and Gutow 2005a). The general strong genetic differentiation observed in $C$. andreae collected from these substrata suggests that prevailing current patterns in the study area may be promoting the low connectivity. In general, in the western Mediterranean, especially in the Alboran basin, the surface circulation patterns are really complex-depending mostly on the Atlantic water input and involving the formation of several gyres (e.g. Ruiz et al. 2002; García-Lafuente et al. 2006). On the other hand, surface currents in the Azores Islands are influenced by the Azorean Currents, the easternmost arm of the Gulf Stream. Additionally, although the main current pattern along the Portuguese coast flows southward, seasonal winds can lead to a reversal of the flowing direction (Relvas et al. 2007). Moreover, there is a branch of the Portugal Current that flows eastward entering the Mediterranean, but the presence of some quasi-permanent cyclonic eddies make its flows difficult. Consequently, the complex current patterns characterising the Atlantic-Mediterranean transition region could restrict rafting episodes on floating objects, so that it does not represent a permanent or semi-permanent connection between populations or regions, and, therefore, leading to a high genetic divergence (see Waters and Roy 2004; Baratti et al. 2005), like we have observed, and eventually even allopatric speciation (Thiel and Haye 2006). In addition, as caprellids are poor swimmers (Thiel et al. 2003), they are not able to switch between spatially separated floating items. Many authors have reported that floating items may become concentrated in convergence zones of wind-induced Langmuir cells, eddies and frontal systems (NimmoSmith and Thorpe 1999; Acha et al. 2003), such as those that characterise the Alboran basin and the Portuguese coast (see above). Here, different floating items may come into direct contact with each other, allowing rafting organisms to switch between rafts (Hobday 2000; Gutow and Franke 2003; Thiel and Gutow 2005a). However, floating objects have a high unpredictability of subsequent encounters with other floating items (Thiel and Gutow 2005b), and switching between rafts does not occur very frequently (Hobday 2000). This also could explain the overall high genetic differentiation found among C. andreae's populations.

Another plausible explanation for the observed genetic patterns of $C$. andreae may be related to its behavioural traits with respect to the substratum on which it settles. Although there is no information about how long caprellids remain in a particular substratum and how often they move to another one, the results obtained in this study suggest that $C$. andreae is quite faithful to its substratum. The near absence of non-shared mtDNA haplotypes between locations sampled may be indicative that $C$. andreae populations settle on the floating substratum, and reproduce probably more than one generation on it. On the other hand, although further investigation involving a more balanced sampling would be needed to ascertain more accurately the genetic patterns obtained, proportionally more diversity was observed in $C$. andreae populations from turtles than those collected from floating objects (Table 2). The complex life history of the turtles with ontogenetically onset migration, repeated movements between foraging, breeding, and nesting areas (Bowen and Karl 2007), increase the probability of establishing contact, thus increasing the opportunities for exchange between their epibionts (Frick et al. 2004; Pfaller et al. 2008) that could explain the higher haplotype and nucleotide diversities in these populations. Moreover, motile rafters appear to be more selective than non-motile ones with respect to their substratum, and may move towards the most suitable floating substratum (Ingólfsson 1998; Thiel and Gutow 2005b). Caprellid amphipods have been found to be relatively unselective with respect to their substratum (McCain 1968; Laubitz 1970). Keith (1971), however, observed that some species show a close dependence on certain substrata that provide several benefits, such as safety against predators and water movement. Both posterior region and crevices in Caretta caretta carapace provide a suitable area for attachment of epibionts, with reduced water flow and, therefore, less physical stress (Pfaller et al. 2006). Lacerda and Masunari (2011) showed that $C$. dilatata individuals were mostly found in structurally complex substrata (highly branched; Caine 1978) and, therefore, may have preferences for specific growth forms of drifting algae. On the other hand, substrata of biotic origin have a high food value for organisms, whereas abiotic substrata (ropes, buoys, etc.) have no food (Thiel and Gutow 2005a). Caprella andreae obtains food by scraping periphyton and encrusting material from the carapace, and newly settled barnacle spat may be removed as the amphipod feeds (Caine 1986). Accordingly, all characteristics previously mentioned, the presence of highly branched algae on carapace turtle (Frick et al. 1998; Kitsos et al. 2005; Pfaller et al. 2008) as well as the higher longevity of sea turtles, indicate that turtle carapaces can provide better conditions than floating objects to increase the probability of survival for $C$. andreae. The presence of highly differentiated haplotypes in the same turtle population is indicative that the turtles host different $C$. andreae populations. Therefore, it can be hypothesised that $C$. andreae is quite faithful to its substratum, and populations may change to turtle carapaces when they have the chance, remaining on them, thus promoting high genetic diversities and population differentiation. If these occur, then rafting on floating objects would 
be sporadic, and current patterns would not be the most important with which to establish the connectivity and population structure, but behavioural traits would be.

\section{Taxonomic issues}

Caprella andreae was found to be paraphyletic in all phylogenetic analyses, based on mitochondrial (COI) and nuclear (18S) markers. All analyses revealed that $C$. andreae specimens from Charleston (CACHA) and Turkey (CATUR) formed a highly differentiated clade $\left(C_{B}\right.$; Fig. 3$)$. The high levels of COI genetic divergence ( $>13 \%$ ) between C. andreae's $C_{\mathrm{A}}$ and $C_{\mathrm{B}}$ is within the interspecific values obtained in this study between the congeneric species $C$. penantis and $C$. dilatata (Table 3 ), as well as those described for other marine peracarid crustaceans (Ashton et al. 2008; Xavier et al. 2009, 2011).

Despite being a highly conserved gene in caprellids, $18 \mathrm{~S}$ proved to have a good discriminatory power for the identification of species within the genus Caprella. The divergence between Clade A and Clade B was considerably higher than that between $C$. penantis and $C$. dilatata (see Table 3). Therefore, according to the above considerations, and the fact that both clades were consistently detected with both markers from different genomes, $C_{\mathrm{A}}$ and $C_{\mathrm{B}}$ most probably represent different species (Lefébure et al. 2006). However, the analysis of morphology does not show a clear differentiation between these clades. This is in line with the results of several recent studies which suggested that many widespread marine invertebrates taxa comprise genetically divergent cryptic species (Sponer and Roy 2002; Moura et al. 2008; Chen and Hares 2011). Additionally, in the order Amphipoda, cryptic speciation has been widely reported, especially for gammarids (Costa et al. 2009; Radulovici et al. 2009; Baird et al. 2011). In this sense, the study carried out by Pilgrim and Darling (2010) is particularly interesting because it provides molecular evidence of cryptic speciation in two introduced biofouling amphipods along the Pacific North American coast (COI genetic divergence ranged from 4.4 to $14 \%$ ). The absence of intraspecific morphological variation in $C$. andreae has been reported in many studies (Mayer 1890; McCain 1968; Krapp-Schickel 1993) and was attributed to an adaptation to live in drifting objects (Aoki and Kikuchi 1995). The results of this study suggest that there is more than one Caprella species that live attached to turtle carapaces or drifting objects. The lack of gene exchange would imply that the species could now evolve independently to new species in the new locations. Probably, their adaptation to ecologically isolated habitats, such as drifting objects, have led to their differentiation and consequent speciation, as reported by Aoki and Kikuchi (1995) for this caprellid species. Though a more detailed analysis is necessary in order to confirm the absence of gene flow, the described pattern can be taken as a strong indication that these could be two distinct species. In addition, a better taxonomic sampling including all, or most, of the recognised species within the genus Caprella might be needed to reach a more detailed and correct view of the genealogy of this genus.

Acknowledgments Special thanks to F. Espinosa, M. VázquezLuis, R. King, M. Sezgin, R. Xavier and the Centro de Recuperación de Especies Marinas Amenazadas (CREMA; Málaga) for providing some of the samples used in the present study. We also thank to M. Branco and R. Xavier for providing valuable comments and suggestions. Financial support of this work was provided by the Ministerio de Educación y Ciencia (Project CGL2011-22474) co-financed by FEDER funds and by the Consejería de Innovación, Ciencia y Empresa, Junta de Andalucía (Project P11-RNM-7041). M. P. Cabezas was supported by a PhD grant 'III Plan Propio de Investigación', from the University of Seville.

\section{References}

Acha EM, Mianzan HW, Iribarne O, Gagliardini DA, Lasta C, Daleo $\mathrm{P}$ (2003) The role of the Río de la Plata bottom salinity front in accumulating debris. Mar Pollut Bull 46:197-202

AMBS Australian Museum Business Services (2002) Port survey for introduced marine species, Sydney harbour. Available online: www.livingharbour.net

Aoki M, Asakura A (1995) Caprellids (Crustacea: Amphipoda: Caprellidae) collected from the Ogasawara (Bonin) Islands. J Nat Hist Museum Chiba 3:191-194

Aoki M, Kikuchi T (1995) Notes on Caprella andreae Mayer, 1890 (Crustacea: Amphipoda) from the carapace of Loggerhead Sea Turtles in the East China Sea and in Kyushu, Japan. Proc Jpn Soc Syst Zool 53:54-61

Ashton GV (2006) Distribution and dispersal of the non-native caprellid amphipod, Caprella mutica Schurin 1935. University of Aberdeen, Dissertation

Ashton GV, Stevens MI, Hart MC, Green DH, Burrows MT, Cook EJ, Willis KJ (2008) Mitochondrial DNA reveals multiple Northern Hemisphere introductions of Caprella mutica (Crustacea, Amphipoda). Mol Ecol 17:1293-1303

Astudillo JC, Bravo M, Dumont CP, Thiel M (2009) Detached aquaculture buoys in the SE Pacific: potential dispersal vehicles for associated organisms. Aquatic Biol 5:219-231

Baird HP, Miller KJ, Stark JS (2011) Evidence of hidden biodiversity, ongoing speciation and diverse patterns of genetic structure in giant Antarctic amphipods. Mol Ecol 20:3439-3454

Baratti M, Goti E, Messana G (2005) High level of genetic differentiation in the marine isopod Sphaeroma terebrans (Crustacea, Isopoda, Sphaeromatidae) as inferred by mitochondrial DNA analysis. J Exp Mar Biol Ecol 315:225-234

Bolten AB, Bjorndal KA, Martins HR, Dellinger T, Biscoito MJ, Encalada SE, Bowen BW (1998) Transatlantic developmental migrations of loggerhead sea turtles demonstrated by mtDNA sequence analysis. Ecol Appl 8:1-7

Boos K (2009) Mechanisms of a successful immigration from northeast Asia: population dynamics, life history traits and interspecific interactions in the caprellid amphipod Caprella mutica Schurin, 1935. Department of Biology, Chemistry and Pharmacy of Freie Universität Berlin, Dissertation

Bosc LAG (1802) Histoire Naturelle des Crustaces. In: Buffon GLL (ed) Histoire Naturelle de Buffon, classee d'apres le system de Linne par R. R. Castel, Paris 
Bowen BW, Karl A (2007) Population genetics and phylogeography of sea turtles. Mol Ecol 16:4886-4907

Bowen BW, Bass AL, Muss A, Carlin JL, Robertson DR (2006) Phylogeography of two Atlantic squirrelfishes (Family Holocentridae): exploring links between pelagic larval duration and population connectivity. Mar Biol 149:899-913

Butler JN (1975) Pelagic tar. Sci Am 232:90-97

Cabezas MP, Guerra-García JM, Baeza-Rojano E, Redondo-Gómez S, Figueroa ME, Luque T, García-Gómez JC (2010) Exploring molecular variation in the cosmopolitan Caprella penantis (Crustacea: Amphipoda): results from RAPD analysis. J Mar Biol Assoc UK 90:617-622

Caine EA (1978) Habitat adaptations of North American caprellid Amphipoda (Crustacea). Biol Bull 155:288-296

Caine EA (1980) Ecology of two littoral species of caprellid amphipods (Crustacea) from Washington, USA. Mar Biol 56:327-335

Caine EA (1986) Carapace epibionts of nesting loggerhead sea turtles: Atlantic coast of USA. J Exp Mar Biol Ecol 95:15-26

Carlton JT (1985) Transoceanic and interoceanic dispersal of coastal marine organisms: the biology of ballast water. Oceanogr Mar Biol Annu Rev 23:313-371

Carlton JT (1987) Patterns of transoceanic marine biological invasions in the Pacific Ocean. Bull Mar Sci 41:452-465

Carr A (1987) New perspectives on the pelagic stage of sea turtle development. Conserv Biol 1:103-121

Castilla JC, Guiñez R (2000) Disjoint geographical distribution of intertidal and nearshore benthic invertebrates in the Southern Hemisphere. Rev Chil Hist Nat 73:585-603

Castresana J (2000) Selection of conserved blocks from multiple alignments for their use in phylogenetic analysis. Mol Biol Evol 17:540-552

Chen G, Hares M (2011) Cryptic diversity and comparative phylogeography of the estuarine copepod Acartia tonsa on the US Atlantic coast. Mol Ecol 20:2425-2441

Chevreux E (1891) Quatrieme campagne de "l'Hirondelle", 1888. Hyale grimaldii et Stenothoe dolfusi. Bulletin de la Société Zoologique de France 16:257-262

Clement M, Posada D, Crandall K (2000) TCS: a computer program to estimate gene genealogies. Mol Ecol 9:1657-1660

Cohen AN, Carlton JT (1998) Accelerating invasion rate in a highly invaded estuary. Science 279:555-558

Colson I, Hughes RN (2004) Rapid recovery of genetic diversity of dogwhelk (Nucella lapillus L.) populations after local extinction and recolonization contradicts predictions from life-history characteristics. Mol Ecol 13:2223-2233

Conlan KE (1990) Revision of the crustacean amphipod genus Jassa Leach (Corophioidea: Ischyroceridae). Can J Zool 68:2031-2075

Costa FO, Henzler CM, Lunt DH, Whiteley NM, Rock J (2009) Probing marine Gammarus (Amphipoda) taxonomy with DNA barcodes. Syst Biodivers 4:365-379

Dana JD (1855) Crustacea. Part II. In: United States Exploring Expedition During the Years 1838, 1839, 1840, 1841, 1842 Under the Command of Charles Wilkes. USN, pp 1-96

David GK, Marshall DJ, Riginos C (2010) Latitudinal variability in spatial genetic structure in the invasive ascidian, Styela plicata. Mar Biol 157:1955-1965

Excoffier L, Lischer HEL (2010) Arlequin suite ver 3.5: a new series of programs to perform population genetics analyses under Linux and Windows. Mol Ecol Resour 10:564-567

Folmer O, Black M, Hoeh W, Lutz R, Vrijenhoek R (1994) DNA primers for amplification of mitochondrial cytochrome $c$ oxidase subunit I from diverse metazoan invertebrates. Mol Mar Biol Biotechnol 3:294-299

Fraser CI, Nikula R, Waters JM (2011) Oceanic rafting by a coastal community. Proc R Soc Lond (Biol) 278:649-655
Frick MG, Williams KL, Robinson M (1998) Epibionts associated with nesting loggerhead sea turtles (Caretta caretta) in Georgia, USA. Herpetol Rev 29:211-214

Frick MG, Williams KL, Markesteyn EJ, Pfaller JB, Frick RE (2004) New records observations of epibionts from loggerhead sea turtles. Southeast Nat 3:613-620

Galil B, Froglia C, Noël P (2002) CIESM Atlas of exotic species in the Mediterranean. Vol 2. Crustaceans-Decapods and stomatopods. CIESM Publishers, Monaco

García-Lafuente J, Delgado J, Criado-Aldeanueva F, Bruno M, del Río J, Vargas JM (2006) Water mass circulation on the continental shelf of the Gulf of Cádiz. Deep-Sea Res II 53:1182-1197

Gollasch S (2002) The importance of ship hull fouling as a vector of species introductions into the North Sea. Biofouling 18:105-121

Goodbody-Gringley G, Vollmer SV, Woollacott RM, Giribet G (2010) Limited gene flow in the brooding coral Favia fragum (Esper, 1797). Mar Biol 157:2591-2602. doi:10.1007/s00227010-1521-6

Guerra-García JM (2001) Habitat use of the Caprellidea (Crustace: Amphipoda) from Ceuta, North Africa. Ophelia 55:27-38

Guerra-García JM, Sánchez-Moyano JE, García-Gómez JC (2000) Redescription of Caprella hirsuta Mayer, 1890 (Crustacea, Amphipoda, Caprellidea) from the Strait of Gibraltar. Misc Zoo 23:69-78

Guerra-García JM, Corzo J, García-Gómez JC (2002) Clinging behaviour of the Caprellidea (Amphipoda) from the Strait of Gibraltar. Crustaceana 75:41-50

Guerra-García JM, Ros M, Gordillo I, Cabezas MP, Baeza-Rojano E, Izquierdo D, Corzo J, Domínguez J, Varona S (2010) Distribution patterns of intertidal and shallow water caprellids associated with macroalgae along the Iberian Peninsula. Zool Baetica 2:101-129

Guerra-García JM, Ros M, Dugo-Cota A, Burgos V, Flores-León AM, Baeza-Rojano E, Cabezas MP, Núñez J (2011) Geographical expansion of the invader Caprella scaura (Crustacea: Amphipoda: Caprellidae) to the East Atlantic coast. Mar Biol 158:2617-2622

Guindon S, Dufayard JF, Lefort V, Anisimova M, Hordijk W, Gascuel O (2010) New algorithms and methods to estimate maximum-likelihood phylogenies: assessing the performance of PhyML 3-0. Syst Biol 59:307-321

Gutow L, Franke HD (2003) Metapopulation structure of the marine isopod Idotea metallica, a species associated with drifting habitat patches. Helgoland Mar Res 56:259-264

Gutow L, Strahl J, Wiencke C, Franke HD, Saborowski R (2006) Behavioural and metabolic adaptations of marine isopods to the rafting life style. Mar Biol 149:821-828

Hall TA (1999) BioEdit: a user-friendly biological sequence alignment editor and analysis program for Windows 95/98/NT. Nucleic Acids Symp Ser 41:95-98

Highsmith RC (1985) Floating and algal rafting as potential dispersal mechanisms in brooding invertebrates. Mar Ecol Prog Ser 25:169-179

Hobday AJ (2000) Persistence and transport of fauna on drifting kelp (Macrocystis pyrifera (L.) C. Agardh) rafts in the Southern California Bight. J Exp Mar Biol Ecol 253:75-96

Hoeksema BW, Roos PJ, Cadée GC (2012) Trans-Atlantic rafting by the brooding reef coral Favia fragum on man-made flotsam. Mar Ecol Prog Ser 445:209-218. doi:10.3354/meps09460

Ingólfsson A (1998) Dynamics of macrofaunal communities of floating seaweed clumps off western Iceland: a study of patches on the surface of the sea. J Exp Mar Biol Ecol 231:119-137

Ito A, Aoki MN, Yahata K, Wada H (2011) Complicated evolution of the caprellid (Crustacea: Malacostraca: Peracarida: Amphipoda) body plan, reacquisition or multiple losses of the thoracic limbs and pleons. Dev Genes Evol 3:133-140 
Jara C, Jaramillo E (1979) Report on a finding of Planes marinus Rathbun, 1914, on a loose buoy in Maiquillahue, Valdivia province, Chile. Medio Ambient 4:108-113

Jensen JL, Bohonak AJ, Kelley ST (2005) Isolation by distance, web service. BMC Genet 6:13

Johannesson K (1988) The paradox of Rockall: why is a brooding gastropod (Littorina saxatilis) more widespread than one having a planktonic larval dispersal stage (L. littorea)? Mar Biol 99:507-513

Karaman GS (1982) Suborder Caprellidea. In: Ruffo S (ed) The Amphipoda of the Mediterranean. Part 1. Mémoires d l'Institut Océanographique, Monaco 13, pp 245-360

Katoh K, Kuma K, Toh H, Miyata T (2005) MAFFT version 5: improvement in accuracy of multiple sequence alignment. Nucleic Acids Res 33:511-518

Keith DE (1971) Substrate selection in caprellid amphipods of southern California, with emphasis on Caprella californica Stimpson and Caprella equilibra Say (Amphipoda). Pac Sci 25:387-394

Kitsos MS, Christodoulou M, Arvanitidis C, Mavidis M, Kirmitzoglou I, Koukouras C (2005) Composition of the organismic assemblage associated with Caretta caretta. J Mar Biol Ass UK 85:256-261

Krapp-Schickel T (1993) Family Gammaridae. In: Ruffo S (ed) The Amphipoda of the Mediterranean. Part 3. Mémoires d l'Institut Océanographique, Monaco, vol 13, pp 773-809

Krapp-Schickel T, Lang C, Libertini A, Melzer RR (2006) Caprella scaura Templeton, 1836 sensu lato (Amphipoda: Caprellidae) in the Mediterranean. Org Divers Evol 6:77-81

Krapp-Schickel T, Rampin M, Libertini A (2008) A cytogenetical study of Ischyroceridae (Amphipoda) allows the identification of a new species, Jassa cadetta sp. N., in the Lagoon of Venice. Org Divers Evol 8:337-345

Krapp-Shickel T, Guerra-García JM, Baeza-Rojano E, Cabezas MP (2011) Taxonomy and ecology of some gammaridean species (Crustacea: Amphipoda) from Tarifa Island, southern Spain. J Mar Biol Assoc UK 91:447-453

Krøyer H (1838) Conspectus Crustaceorum Groenlandiae. Naturhistorisk Tidsskrift 2:249-261

Krøyer H (1843) De hidtil bekjende nordiske Krangon-Arter. Naturhistorisk Tidsskrift 4:217-276

Lacerda MB, Masunari S (2011) Substrate selection of the caprellid Caprella dilatata (Crustacea, Amphipoda). Rev biol mar oceanogr 46:207-218

Laubitz DR (1970) Studies on the Caprellidae (Crustacea, Amphipoda) of the American North Pacific, National Museum of Canada

Leach WE (1814) Crustaceology. In: Brewster D (ed) The Edinburgh Encyclopaedia. Blackwood, pp 383-437

Lefébure T, Douady CJ, Gouy M, Gibert J (2006) Relationship between morphological taxonomy and molecular divergence within Crustacea: proposal of a molecular threshold to help species delimitation. Mol Phylogenet Evol 40:435-447

Lester SE, Ruttenberg BI (2005) The relationship between pelagic larval duration and range size in tropical reef fishes: a synthetic analysis. Proc R Soc Lond (Biol) 272:585-591

Librado P, Rozas J (2009) DnaSP v5: a software for comprehensive analysis of DNA polymorphism data. Bioinformatics 25:14511452

Linnaeus C (1758) Systema Naturae per regna tria naturae, secundum classes, ordines, genera, species, cum characteribus, differentiis, synonymis, locis. In: Salvius L (ed), 10th edn. Holmiae, pp 824

Linnaeus C (1767) Systema naturae sive regna tria naturae, secundum classes, ordines, genera, species, cum characteribus, differentiis, synonymis, locis. In: Salvius L (ed) 12th edn. Holmiae, pp 533-1327
Locke A, Corey S (1989) Amphipods, isopods and surface currents: a case for passive dispersal in the Bay of Fundy, Canada. J Plankton Res 11:419-430

Martínez J, Adarraga I (2008) First record of invasive caprellid Caprella scaura Templeton, 1836 sensu lato (Crustacea: Amphipoda: Caprellidae) from the Iberian Peninsula. Aquat Invasions 3:165-171

Mayer P (1890) Die Caprelliden des Golfes von Neapel und der angrenzenden Meeres Abschinitte. Fauna Flora Golf Neapel 17:1-55

McCain JC (1968) The Caprellidea (Crustacea: Amphipoda) of the western North Atlantic. Bull U S Natl Mus 278:1-116

Mcgrath D, Myers AA (1989) The drift amphipod Hyale grimaldii in Irish and British waters. J Mar Biol Assoc UK 69:913-918

Moura CJ, Harris DJ, Cunha MR, Rogers AD (2008) DNA barcoding reveals cryptic diversity in marine hydroids (Cnidaria, Hydrozoa) from coastal and deep-sea environments. Zool Scripta 37:93-108

NimmoSmith WAM, Thorpe SA (1999) Dispersion of buoyant material by Langmuir circulation and a tidal current. Mar Pollut Bull 38:824-829

Nunes FLD, Norris RD, Knowlton N (2011) Long distance dispersal and connectivity in amphi-atlantic corals at regional and basin scales. PLoS ONE 6:e22298. doi:10.1371/journal.pone.0022298

Ó Foighil D, Jennings R, Park JK, Merriwether DA (2001) Phylogenetic relationships of mid-oceanic ridge and continental lineages of Lasaea spp. (Mollusca: Bivalvia) in the northeastern Atlantic. Mar Ecol Prog Ser 213:165-175

Palumbi SR (2003) Population genetics, demographic connectivity, and the design of marine reserves. Ecol Appl 13:146-158

Pereira SG, Lima FP, Queiroz NC, Ribeiro PA, Santos AM (2006) Biogeographic patterns of intertidal macroinvertebrates and their association with macroalgae distribution along the Portuguese coast. Hydrobiologia 555:185-192

Pfaller JB, Bjorndal KA, Reich KJ, Frick MG, Williams KL (2006) Distribution patterns of epibionts on the carapace of loggerhead turtles, Caretta caretta. J Mar Biol Assoc UK Biodiversity Records [internet] 5381:1-4. Available from: http://www.mba. ac.uk/jmba/jmba2biodiversityrecords.php

Pfaller JB, Frick MG, Reich KJ, Williams KL, Bjorndal KA (2008) Carapace epibionts of Loggerhead Sea turtles (Caretta caretta) nesting at Canaveral National Seashore, Florida. J Nat Hist 42:1095-1102

Pilgrim EM, Darling JA (2010) Genetic diversity in two introduced biofouling amphipods (Ampithoe valida \& Jassa marmorata) along the Pacific North American coast: investigation into molecular identification and cryptic diversity. Divers Distrib $16: 827-839$

Posada D (2008) jModelTest: phylogenetic model averaging. Mol Biol Evol 25:1253-1256

Prato E, Biandolino F (2005) Amphipod biodiversity of shallow water in the Taranto seas (north-western Ionian Sea). J Mar Biol Ass UK 85:333-338

Radulovici AE, Sainte-Marie B, Dufresne F (2009) DNA barcoding of marine crustaceans from the Estuary and Gulf of St Lawrence: a regional-scale approach. Mole Ecol Resour 9:181-187

Rambaut A, Drummond AJ (2007) Tracer v1.4, Available from http://beast.bio.ed.ac.uk/Tracer

Rawson PD, Macnamee R, Frick MG, Williams KL (2003) Phylogeography of the coronulid barnacle, Chelonibia testudinaria, from loggerhead sea turtles, Caretta caretta. Mol Ecol 12:26972706

Relvas P, Barton ED, Dubert J, Oliveira PB, Peliz A, Da Silva JCB, Santos AMP (2007) Physical oceanography of the western Iberia ecosystem: latest views and challenges. Prog Oceanogr 74:149-173 
Ribeiro PA, Branco M, Hawkins SJ, Santos AM (2010) Recent changes in the distribution of a marine gastropod, Patella rustica, across the Iberian Atlantic coast did not result in diminished genetic diversity or increased connectivity. J Biogeogr 37:1782-1796

Richards VP, Thomas JD, Stanhope MJ, Shivji MS (2007) Genetic connectivity in the Florida reef system: comparative phylogeography of commensal invertebrates with contrasting reproductive strategies. Mol Ecol 16:139-157

Ronquist F, Huelsenbeck JP (2003) MRBAYES 3: bayesian phylogenetic inference under mixed models. Bioinformatics 19:15721574

Roussel De Vauzème DM (1834) Mémoire sur le Cyamus ceti (Latr.) de la classe des Crustacés. Annales des Sciences Naturelles, Zoologie, Série 2, 1, pp 239-255; 257-265

Rozen S, Skaletsky H (2000) Primer3 on the www for general users and for biologist programmers. Methods Mol Biol 132:365-386

Ruffo S (1993) The Amphipoda of the Mediterranean. Part 3: Gammaridea (Melphidippidae to Talitridae), Ingolfiellidea, Caprellidea. Mémoires de l'Institut Océanographique, Monaco, vol 13, pp 576-813

Ruiz S, Font J, Emelianov M, Isern-Fontanet J, Millot C, Salas J, Taupier-Letage I (2002) Deep structure of an open sea eddy in the Algerian Basin. J Mar Syst 33-34:179-195

Sano M, Omori M, Taniguchi K (2003) Predator-prey systems of drifting seaweed communities off the Tohoju coast, northern Japan, as determined by feeding habitat analysis of phytal animals. Fish Sci 69:260-268

Scheltema RS (1988) Initial evidence for the transport of teleplanic larvae of benthic invertebrates across the East Pacific barrier. Biol Bull (Woods Hole) 174:145-152

Schurin A (1935) Zur Fauna der Caprelliden der Bucht Peters des Großen (Japanisches Meer). Zoologischer Anzeiger 112:198-203

Sezgin M, Ateş AS, Katağan T, Bakir K, Yalçin Özdilek Ş (2009) Notes on amphipods Caprella andreae Mayer, 1890 and Podocerus chenlonophilus (Chevreux \& Guerne, 1888) collected from the loggerhead sea turtle, Caretta caretta, off the Mediterranean and the Aegean coast of Turkey. Turk J Zool 33:433-437

Sherman CDH, Hunt A, Ayre DJ (2008) Is life history a barrier to dispersal? Contrasting patterns of genetic differentiation along an oceanographically complex coast. Biol J Linn Soc 95:106-116

Sponer R, Roy MS (2002) Phylogeographic analysis of the brooding brittle star Amphipholis squamata (Echinodermata) along the coast of New Zealand reveals high cryptic genetic variation and cryptic dispersal potential. Evolution 56:1954-1967

Strathmann RR, Hughes TP, Kuris AM, Lindeman KC, Morgan SG, Pandolfi JM, Warner RR (2002) Evolution of local recruitment and its consequences for marine populations. Bull Mar Sci 70:377-396

Suárez-Morales E, Morales-Vela B, Padilla-Saldívar J, Silva-Briano M (2010) The copepod Balaenophilus manatorum (Ortíz, Lalana and Torres) (Harpacticoida), an epibiont of the Caribbean manatee. J Nat Hist 44:847-859

Takeuchi I, Hirano R (1995) Clinging behavior of the epifaunal caprellids (Amphipoda) inhahibiting the Sargassum zone on the Pacific coast of Japan, with its evolutionary implications. J Crust Biol 15:481-492

Takeuchi I, Sawamoto S (1998) Distribution of caprellid amphipods (Crustacea) in the western North Pacific based on the CSK International Zooplankton Collection. Plankton Biol Ecol 45:225-230

Tamura K, Peterson D, Peterson N, Stecher G, Nei M, Kumar S (2011) MEGA5: molecular evolutionary genetics analysis using maximum likelihood, evolutionary distance, and maximum parsimony methods. Mol Biol Evol 28:2731-2739. doi:10.1093/ molbev/msr121
Templeton R (1836) Descriptions of some undescribed exotic Crustacea. Trans Entomol Soc Lond 1:185-198

Teske PR, Hamilton H, Palsbøll PJ, Choo CK, Gabr H, Lourie SA, Santos M, Sreepada A, Cherry MI, Matthee CA (2005) Molecular evidence for long-distance colonization in an IndoPacific seahorse lineage. Mar Ecol Prog Ser 286:249-260

Teske PR, Papadopoulos I, Zardi GI, Mcquaid CD, Edkins MT, Griffiths GL, Barker NP (2007) Implications of life history for genetic structure and migration rates of southern African coastal invertebrates: planktonic, abbreviated and direct development. Mar Biol 152:697-711

Thiel M (2003) Extended parental care in crustaceans-an updateRev Chil. Hist Nat 76:205-218

Thiel M, Gutow L (2005a) The ecology of rafting in the marine environment. I. The floating substrata. Oceanogr Mar Biol Annu Rev 42:181-263

Thiel M, Gutow L (2005b) The ecology of rafting in the marine environment. II. The rafting organisms and community. Oceanogr Mar Biol Annu Rev 43:279-418

Thiel M, Haye PA (2006) The ecology of rafting in the marine environment. III. Biogeographical and evolutionary consequences. Oceanogr Mar Biol Annu Rev 44:323-429

Thiel M, Guerra-García JM, Lancellotti DA, Vásquez N (2003) The distribution of littoral caprellids (Crustacea: Amphipoda: Caprellidea) along the Pacific coast of continental Chile. Rev Chil Hist Nat 76:297-312

Thompson JD, Higgins DG, Gibson TJ (1994) CLUSTAL W: improving the sensitivity of progressive multiple sequence alignment through sequence weighting, position-specific gap penalties and weight matrix choice. Nucleic Acids Res 22:4673-4680

Torres-Pratts H, Schärer MT, Schizas NV (2009) Genetic diversity of Chelonibia caretta, commensal barnacles of the endangered hawskill sea turtle Eretmochelys imbricate from the Caribbean (Puerto Rico). J Mar Biol Assoc UK 89:719-725

Van der Baan SM, Holthuis LB (1969) On the occurrence of Isopoda in the surface plankton in the North Sea newar the lightship "Texel". Neth J Sea Res 4:354-363

Waters JM (2011) Competitive exclusion: phylogeography's 'elephant in the room'? Mol Ecol 20:4388-4394

Waters JM, Roy MS (2004) Out of Africa: the slow train to Australasia. Syst Biol 53:18-24

Whiting MF (2002) Mecoptera is paraphyletic: multiple genes and phylogeny of Mecoptera and Siphonaptera.Zool Scripta 31:93-104

Xavier R (2011) Phylogeny and phylogeography of the marine isopod genus Stenosoma: Taxonomical revision and analysis of changes in species' distributions. Faculdade de Ciências da Universidade do Porto, Dissertation

Xavier R, Santos AM, Lima FP, Branco M (2009) Invasion or invisibility: using genetic and distributional data to investigate the alien or indigenous status of the Atlantic populations of the peracarid isopod, Stenosoma nadejda (Rezig 1989). Mol Ecol 18:3283-3290

Xavier R, Zenboudji S, Lima FP, Harris DJ, Santos AM, Branco M (2011) Phylogeography of the marine isopod Stenosoma nadejda (Rezig, 1989) in North African Atlantic and western Mediterranean coasts reveals complex differentiation patterns and a new species. Biol J Linnean Soc 104:419-431

Xavier R, Santos AM, Branco M (2012) MtDNA and nuclear data reveal patterns of low genetic differentiation for the isopods Stenosoma lancifer and Stenosoma acuminatum, with low dispersal ability along the northeast Atlantic coast. Sci Mar 76:133-140. doi:10.3989/scimar.03373.29A

Zakhama-Sraieb R, Karaa S, Bradai MN, Jribi I, Charfi-Cheikhrouha C (2010) Amphipod epibionts of the sea turtles Caretta caretta and Chelonia mydas from the Gulf of Gabès (central Mediterranean). Mar Biodivers Rec 3:1-4. doi:10.1017/S1755267210000333 